\title{
Klasifikasi Keterampilan Kognitif Menggunakan Metode Learning Vector Quantization dengan Bantuan Game
}

\author{
Budi Irawan, Joan Santoso \\ Departemen Teknologi Informasi, Institut Sains dan Teknologi Terpadu Surabaya \\ E-mail: joan@stts.edu
}

\begin{abstract}
Abstrak-Untuk mengukur tingkat kognitif seorang siswa sangatlah sulit banyak indikator yang mempengaruhi yang menyebabkan hasilnya tidak akurat. Dengan metode serius game ini diharapkan akan diketahui tingkat kognitif seorang siswa sebagai pemain. Dalam serius game ini penguasaan pembelajaran merupakan inti dari proses belajar mengajar. Untuk mendapatkan hasil output tingkat klasifikasi keterampilan kognitif siswa sebagai pemain, pemain akan menjawab pertanyaan pada permainan Cognitive Skill Game (CSG) ini. Siswa sebagai pemain akan dipantau bagaimana berinteraksi dengan permainan untuk meningkatkan konsep permainan kognitif ini. Pada CSG ini metode yang digunakan adalah Learning Vector Quantization (LVQ) yang berfungsi untuk mengoptimalkan proses klasifikasi keterampilan kognitif pemain sebagai output setelah menyelesaikan permainan. Guru sebagai data training digunakan untuk mengobservasi LVQ. Guru mempunyai pengalaman yang banyak dan mempunyai banyak sertifikasi atau pelatihan dianggap cocok sebagai data training. Pengambilan data Guru menggunakan metode observasi kuesioner. Siswa jurusan Teknik Komputer dan Jaringan (TKJ) SMK adalah populasi klasifikasi keterampilan kognitif saat menjalankan permainan dalam penelitian. Sebagian kecil pemain CSG masuk dalam kategori keterampilan kognitif hati-hati, beberapa masuk dalam kategori ahli, dan sebagian besar masuk dalam dalam kategori coba-coba. Hasil dari permainan CSG ini adalah pemain memiliki kemampuan keterampilan kognitif masih rendah. High trial and error $75 \%$, high expert $6 \%$, dan high careful 19\%. Dalam penelitian ini juga dilakukan validasi pengukuran secara berulang-ulang untuk mengetahui keakuratan klasifikasi CSG.
\end{abstract}

Kata Kunci-CSG, Klasifikasi Kognitif, Kognitif, LVQ

\section{Pendahuluan}

$\mathrm{U}$ ntuk mengukur tingkat kognitif seorang siswa sangatlah sulit banyak indikator yang mempengaruhi yang menyebabkan hasilnya tidak akurat, penyebabnya bisa banyaknya parameter yang bersifat bias, tidak bisa dijadikan ukuran, dan merupakan tes yang invalid. Dengan serius game ini akan diketahui tingkat kognitif seorang siswa sebagai pemain.[1] Dalam serius game ini penguasaan

Naskah Masuk : 2 Maret 2021

Naskah Direvisi : 12 April 2021

Naskah Diterima : 21 April 2021 pembelajaran merupakan inti dari proses belajar mengajar.[2] Metode Cognitive Skill Game (CSG) yang digunakan pada serius game ini pemain harus menjawab pertanyaan teori tentang materi mata pelajaran produktif pada jurusannya. Setiap stage mempunyai jenis pertanyaan yang berbeda.

CSG adalah model pengukuran secara tidak langsung dari tingkat kognitif, pemain diharapkan tidak akan mengalami kebosanan dalam bermain. Pada CSG nilai kognitif diambil dari indikator yang muncul selama permainan berlangsung. Dengan demikian CSG akan menghilangkan manipulasi data pada tes pembelajaran dalam serious games. Siswa sebagai pemain akan dipantau bagaimana berinteraksi dengan permainan untuk meningkatkan konsep permainan kognitif ini. Pada CSG ini menggunakan metode Learning Vector Quantization (LVQ) yang berfungsi untuk mengoptimalkan input klasifikasi keterampilan kognitif pemain.[3] Metode LVQ akan diuji seberapa akurat dan valid saat diterapkan pada CSG ini. Pembuatan CSG ini bertujuan untuk mengembangkan desain dan metode untuk klasifikasi keterampilan kognitif berbasis kecerdasan buatan pedagogik, ketika pemain memainkan CSG ini. Guru sebagai data training digunakan untuk mengobservasi LVQ.[3] Guru mempunyai pengalaman yang banyak dan mempunyai banyak sertifikasi atau pelatihan dianggap cocok sebagai data training. Pengambilan data Guru menggunakan metode observasi kuesioner. Siswa jurusan Teknik Komputer dan Jaringan (TKJ) SMK adalah populasi klasifikasi keterampilan kognitif saat menjalankan permainan dalam penelitian. Sebagian kecil pemain CSG masuk dalam kategori keterampilan kognitif hati-hati, beberapa masuk dalam kategori ahli, dan sebagian besar masuk dalam dalam kategori coba-coba.[4] Dari penelitian dapat disimpulkan hasil dari CSG ini adalah kemampuan pemain masih rendah.

\section{TinjauAn PUSTAKA}

\section{A. Serious Game}

Serious Game[5][6][7] merupakan kontes mental melalui bermain dengan komputer sesuai dengan aturan khusus yang menggunakan hiburan dengan sasaran untuk pemerintahan atau pelatihan pada perusahaan, pendidikan, kesehatan, kebijakan publik, dan komunikasi strategis. Tujuan 
pengembangan serius game adalah untuk kepentingan penelitian yang tidak untuk komersial.

Serious game telah berkembang pesat sebagai alat atau media alternatif dalam bidang bisnis dan edukasi, seperti advergame dan training game dimana fokus yang menjadi perhatian saat ini adalah pengembangan konten yang dapat menyampaikan tujuan dari simulasi itu sendiri.

\section{B. Cognitive Skill Game}

Cognitive Skill Game (CSG)[8][9] adalah permainan yang mengklasifikasikan keterampilan kognitif pemain berbasis kecerdasan buatan pedagogik. Hal ini lebih menekankan pada pencapaian tingkat kemampuan, misalnya, menghitung jumlah item yang benar dan yang salah, serta tingkat kompetensi dengan mempertimbangkan bobot kesalahan, kebenaran, dan pembatalan. Kelemahan dari pengukuran berbasis hasil tidak mempertimbangkan karakteristik aksi pemain dalam menyelesaikan misi selama permainan. Karakteristik pemain dalam permainan merupakan bentuk keterampilan kognitif dalam proses.

Dalam permainan CSG dibagi menjadi tiga bagian utama, yaitu; kognitif keterampilan yang tinggi (expert), keterampilan kognitif menengah (carefully), dan keterampilan kognitif yang rendah (trial and error). Dari bagian-bagian tersebut memiliki karakteristik multi-obyektif karena ukuran yang digunakan dari masing-masing indikator berlawanan.[9]

Expert sering disebut untuk memprediksi kinerja siswa, tetapi kemampuan expert dapat mempengaruhi heuristik kognitif untuk memanfaatkan pengetahuan unggul mereka dalam memprediksi kinerja tugasnya.[10]

Carefully merupakan kegiatan kognitif yang penuh pertimbangan dan tidak gegabah. Pekerjaan hati-hati (careful) akan menjauhkan seseorang dari membuat kesalahan. Berpikir hati-hati (think carefully) tentang risiko atau kemungkinan konsekuensi yang ada, merupakan cara membuat keputusan yang baik.[9]

Seseorang belajar dengan trial and error jika mereka sesekali ingin mencoba strategi baru atau menolak pilihan yang salah, dalam arti bahwa mereka tidak hanya mengarah untuk hadiah yang lebih tinggi. Pembelajaran trial and error sangat tidak efisien dan mempunyai potensi cukup berbahaya dalam situasi dimana efek kegagalannya tinggi atau untuk kondisi yang lebih mementingkan belajar dengan cepat.[9] [4]

CSG memiliki sembilan hasil probabilitas, yaitu; 1) trial and error yang rendah, 2) setengah trial and error, 3) trial and error yang tinggi, 4) carefully yang rendah, 5) setengah carefully, 6) carefully yang tinggi, 7) expert yang rendah, 8) setengah expert dan 9) expert yang tinggi.[3]

\section{Learning Vector Quantization (LVQ)}

Banyak metode dapat digunakan untuk mengklasifikasi data. Learning Vector Quantization (LVQ) adalah metode klasifikasi data yang digunakan dalam penelitian ini.[11][12] LVQ adalah Jaringan Syaraf Tiruan (JST) terawasi dengan menggunakan metode pembelajaran yang kompetitif dikembangkan oleh Kohonen dkk.[13], yang digunakan dalam pelatihan terpandu dari lapisan dalam kompetisi JST. Lapisan kompetitif akan secara otomatis belajar untuk meningkatkan klasifikasi kinerja masukan vektor secara berkala. Ketika beberapa masukan memiliki vektor yang jaraknya sangat dekat, vektor tersebut akan dikelompokkan dalam beberapa kelas.

$$
c=\operatorname{argmin}\left\|x-w_{j}\right\|
$$

Fungsi matematis metode LVQ ditunjukkan pada persamaan dibawah ini Algoritma LVQ mencakup proses belajar dan mengingat. Dalam proses pembelajaran, dalam rangka mencapai klasifikasi akurat, jarak Euclidean (Di) yang digunakan sebagai aturan dasar kompetisi seperti pada persamaan dibawah ini. [6]

$$
D_{j}=\left\|x-w_{j}\right\|=\sqrt{\sum_{i}\left(x_{i}-w_{i j}\right)^{2}}
$$

\section{Finite State Machine (FSM)}

Finite State Machine (FSM) adalah sebuah metodologi perancangan sistem kontrol yang menggambarkan tingkah laku atau prinsip kerja sistem dengan menggunakan tiga hal berikut: State(Keadaan), Event(kejadian) dan action(aksi). Peneliti menggunakan metode ini untuk membantu mengontrol alur dari game pendidikan tersebut. Dibawah ini gambar dari Alurnya.[14]

Menurut Mayovio dkk. Finite State Machine (FSM) merupakan sebuah algoritma yang berisi behavior dari sebuah agen. FSM memiliki beberapa unsur utama, yaitu State, Event, Transition, dan Action. Disamping setiap state terdapat transition yang digunakan untuk mengubah state yang ada pada agen. Transition akan tertrigger apabila beberapa kondisi sudah dicapai oleh agen.[15][16]

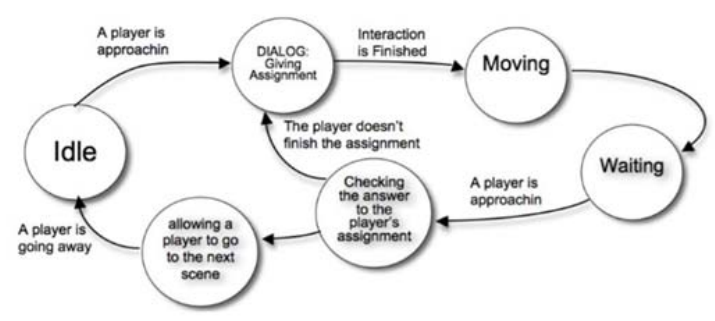

Gambar. 1. Model FSM Game Pendidikan [17]

\section{E. GameMaker Studio 2}

GameMaker Studio 2,[18] pada awal munculnya dibuat dari software pengelola aplikasi Animo yang dikembangkan oleh Mark Overmars menggunakan bahasa pemrograman Delphi. Pada versi awal tanpilan user interface dari game ini tidak user friendly karena memiliki interface terpisah antar komponen Windows yang membuat kesulitan bagi pengguna. Setelah GameMaker 4 dirilis, ada perubahan yang cukup signifikan komponen yang tadinya terpisah sekarang tergabung menjadi satu windows dan sudah dapat membuat game dengan mudah.

GameMaker versi 6 sudah didukung dengan 3D grafis sederhana yang memungkinkan seorang delover game membuat game 3D namum kualitasnya masih sangat kurang. Baru pada versi terakhir, GameMaker Studio 2 menggunakan metode grafis berbasis png yang support pada teknologi alpha channel sehingga grafis yang dihasilkan semakin halus. 


\section{Metode Dan Inti Penelitian}

Pada pokok bahasan ini akan dibahas mengenai desain arsitektur dari system, alternative algoritma yang akan digunakan.

\section{A. Perancangan FSM dalam CSG}

Pengembangan FSM digunakan untuk menentukan action (aksi) objek bagaimana karakter bereaksi atau memutuskan tindakan berdasarkan state (keadaan) situasi atau event (kejadian) tertentu. Berikut adalah keterangan karakter dari pemain:
1) $\mathrm{Q} 0=$ State diam
2) $\mathrm{Q} 1=$ State masuk ruang

$$
\mathrm{a}=\text { input }
$$$$
\mathrm{x}=\text { output }
$$
3) $\mathrm{Q} 2=$ State keluar ruang
4) $\mathrm{Q} 3=$ State selesai

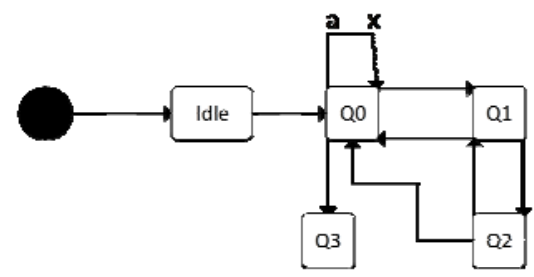

Gambar. 2. Model FSM Pada Karakter

Situasi mempermudah pada permainan CSG ini akan dibuatkan alur algoritma menggunakan FSM untuk mempermudah dan membuat game menjadi lebih interatif. Berikut penerapan pada FSM pada permainan CSG dapat dilihat pada skema perancangan dibawah ini.

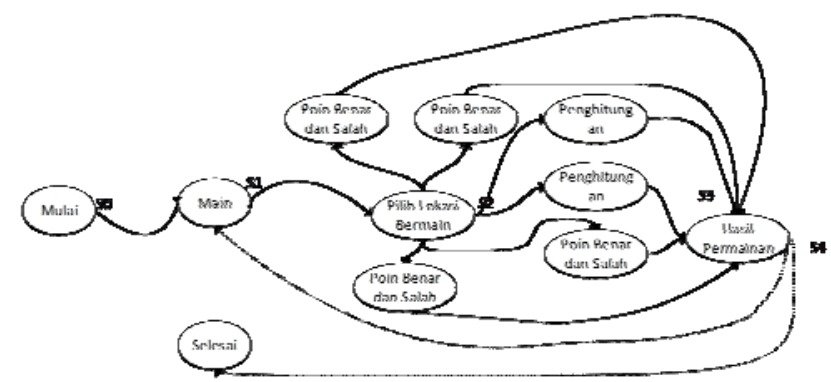

Gambar. 3. Model FSM Pada CSG

Detail permainan CSG model dengan FSM ditunjukkan pada Gambar 3 yang merupakan penjabaran lebih detail dari Gambar 2. Dari gambar tersebut dapat dijelaskan bahwa model permainan ini.

\section{B. Klasifikasi CSG}

Misalnya A adalah kemampuan Kognitif yang berisi semua item keterampilan dengan bentuk melakukan tes atau semua item kompetisi dalam suatu permainan. Jumlah item keterampilan (dalam tes) / kompetisi (dalam permainan) adalah $A=\{b, c, d\}$. Dimana $b, c$, dan $d$ adalah parameter pemain dalam bermain game. $b$ adalah jumlah jawaban yang benar dalam tes atau jumlah kemenangan dalam permainan, $d$ adalah jumlah kesalahan dalam tes atau jumlah kekalahan dalam permainan, dan $c$ adalah jumlah ragu-ragu (kegagalan) dalam tes atau menghindar (melarikan diri) dari kompetisi dalam permainan.

$g h=\{b, d\}$ adalah kondisi ketika pemain mencoba untuk menjawab sejumlah tes atau mencoba untuk menyelesaikan

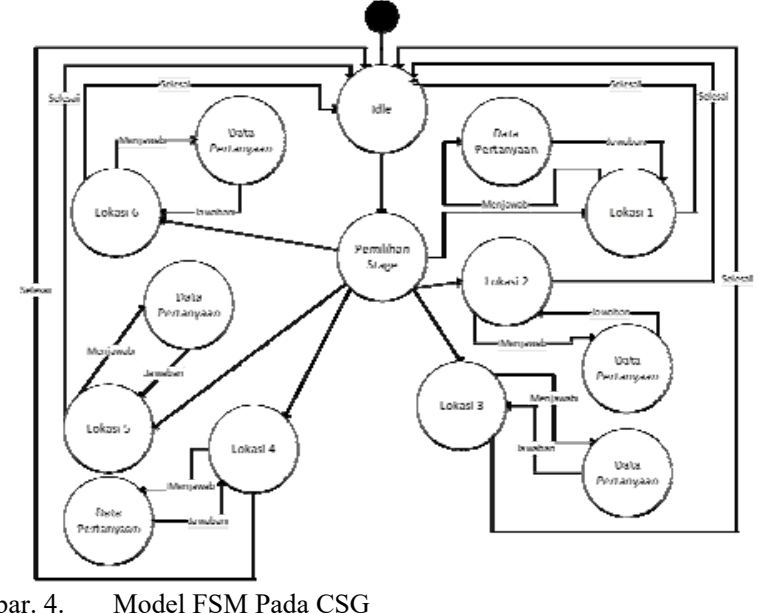

semua kompetisi pemodelan CSG yang juga merupakan indikasi item pemain tentang kebenaran/ kemenangan dan kesalahan/ kekalahan.

$$
g h=(b+d) / 2
$$

$e=\{0.5 b, 0.3 d, 0.2 c\}$ adalah kecakapan atau kemampuan diri dan juga $q=\{b, c, d\}$ yang merupakan sejumlah pengambilan pertanyaan dari semua tes atau memainkan sejumlah kompetisi dalam permainan, yang merupakan isi dari karakter pemain dalam kesalahan, item yang benar, dan keraguan dalam permainan.

$$
\begin{gathered}
e=0.5 b+0.3 d+0.2 c \\
f=(b+c+d) / 3
\end{gathered}
$$

Dari formula diatas dapat dihasilkan tiga type klasifikasi CSG yaitu, type trial and error, type carefully, dan type expert. $f \in$ te, tr $\in$ te, $t e=\{\{b, c, d\},\{b, d\}, d, c\}$ adalah type trial and error yang berisi; mengambil pertanyaan, mencoba untuk menjawab, kesalahan, dan ketidakpastian. $q \in c f$, $c f=\{\{b, d, c\}, d, c\}$ adalah type carefully yang berisi; mengambil pertanyaan, kesalahan dan ketidakpastian. Sedangkan, $q \in e p, e \in e p, e p=\{\{b, m, c\},\{0.5 b, 0.3 m, 0.2 c\}$, $m, c\}$ adalah domain expert yang berisi; mengambil pertanyaan, kemampuan diri, kesalahan, dan ketidakpastian. Untuk melakukan klasifikasi domain ini adalah menggunakan metode LVQ.

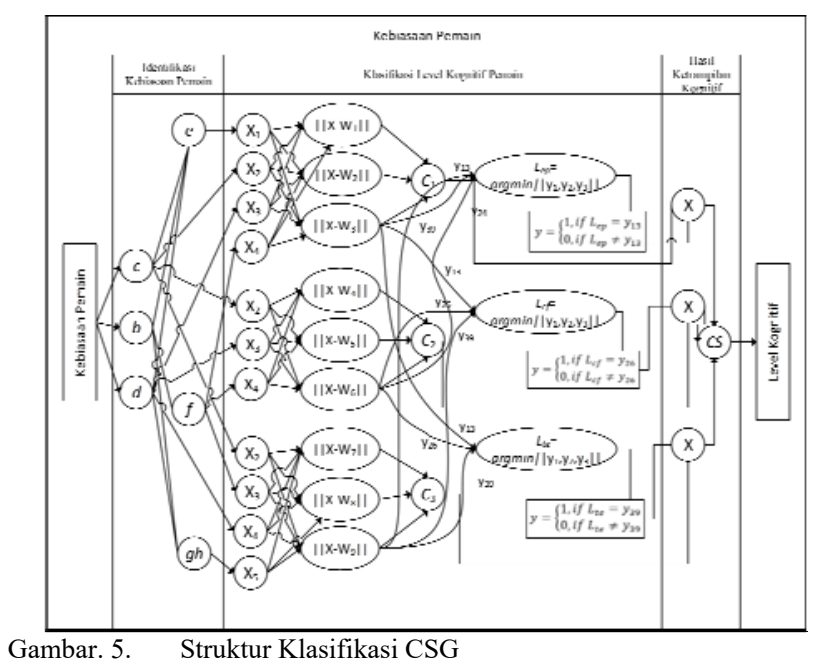


Tabel 1. Keterangan Klasifikasi CSG

\begin{tabular}{|c|c|c|c|}
\hline Simbol & Penjelasan & Simbol & Penjelasan \\
\hline C & Input dari player (cancel/escape) & $\mathrm{W}_{1}$ & Bobot vector Low Expert \\
\hline$b$ & Input dari player (jawaban benar/menang) & $\mathrm{W}_{2}$ & Bobot vector Semi Expert \\
\hline$d$ & Input dari player (jawaban salah/kalah) & $\mathrm{W}_{3}$ & Bobot vector High Expert \\
\hline$e$ & Nilai kemampuan player & $\mathrm{W}_{4}$ & Bobot vector Low Carefull \\
\hline$f$ & $\begin{array}{l}\text { Nilai jawaban pilihan player/menjalankan } \\
\text { permainan }\end{array}$ & $\mathrm{W}_{5}$ & Bobot vector Semi Carefull \\
\hline$g h$ & $\begin{array}{l}\text { Nilai untuk mencoba pertanyaan/memcoba untuk } \\
\text { menyelesaikan }\end{array}$ & $\mathrm{W}_{6}$ & Bobot vector High Carefull \\
\hline $\mathrm{X}_{1}$ & Input vector kemampuan $(e)$ & $\mathrm{W}_{7}$ & Bobot vector Low Trial and Error \\
\hline $\mathrm{X}_{2}$ & Input vector cancel $(c)$ & $\mathrm{W}_{8}$ & Bobot vector Semi Trial and Error \\
\hline $\mathrm{X}_{3}$ & Input vector escape $(d)$ & $C_{1}$ & Class of Expert Level Classification $\left(C_{j, e p}\right)$ \\
\hline $\mathrm{X}_{4}$ & Input vector salah/kalah $(q)$ & $C_{2}$ & Class of Careful Level Classification $\left(C_{j, c f}\right)$ \\
\hline $\mathrm{X}_{5}$ & Input vector mencoba menjawab/selesai $(g h)$ & $C_{3}$ & Class of Trial and Error Level Classification $\left(C_{j, t e}\right)$ \\
\hline $\begin{array}{l}\| \mathrm{X}- \\
\mathrm{W}_{3} \|\end{array}$ & $\begin{array}{l}\text { Jarak antara input vector }(\mathrm{x}) \text { dan nilai vector } \mathrm{W}_{\mathrm{n}} \\
\text { (Hidden Layer) }\end{array}$ & $\mathrm{y}_{13}$ & Output of High Expert (ep) \\
\hline $\mathrm{X}$ & Input vector $\left(X=\left\{X_{1}, X_{2 \ldots} X_{5}\right\}\right)$ & $y_{26}$ & Output of High Careful $(c f)$ \\
\hline $\mathrm{W}_{\mathrm{n}}$ & Bobot vector untuk output nilai & $\mathrm{y}_{39}$ & Output of High Trial and Error (te) \\
\hline$C S$ & Output Classification of CSG & $L$ & Cognitive Skill Type \\
\hline
\end{tabular}

$L=(s, j)$ adalah menggambarkan $\mathrm{CSG},[6] \mathrm{s}$ adalah notasi dari tiga type di $\mathrm{CSG}$, dan $\mathrm{j}$ adalah tiga tingkatan dalam setiap domain. L memiliki sembilan hasil sub type yang disebut kelas CSG, yaitu; 1) trial and error yang rendah, 2) setengah trial and error, 3) trial and error yang tinggi, 4) carefully yang rendah, 5) setengah carefully, 6) carefully yang tinggi, 7) expert yang rendah, 8) setengah expert dan 9) expert yang tinggi.

\section{Metode LVQ dalam CSG}

Metode LVQ digunakan untuk mengklasifikasikan data vektor masukan dalam CSG menjadi tiga type. Vektor input LVQ adalah bobot variabel dalam CSG, yaitu bobot untuk; mencoba menjawab, mengambil pertanyaan, kompetensi, kesalahan, dan pembatalan. Hasil dari LVQ berupa tiga kelompok jenis data keterampilan kognitif, yaitu; trial and error (te), careful (cf) dan expert (ep). Untuk masingmasing kelompok keterampilan kognitif terdapat tiga tingkatan didalamnya, yaitu; keterampilan kognitif tingkat tinggi, keterampilan kognitif menengah dan keterampilan kognitif yang rendah.

$$
\begin{aligned}
& x_{2, t e} \Leftrightarrow C, x_{3, t e} \Leftrightarrow m, x_{4, t e} \Leftrightarrow q, x_{5, t e} \Leftrightarrow t r \\
& t e_{j}=\sqrt{\sum_{i}\left(x_{i, t e}-w_{j, t e}\right)^{2}} \\
& C_{j, t e}=\arg \min \left\|x_{t e}-w_{j, t e}\right\|
\end{aligned}
$$

te $e_{j}$ adalah nilai trial and error dalam CSG (dalam formula 1 dan 2), dan $C j$, te adalah klasifikasi tingkatan trial and error (dalam formula 3). Tiga kelas trial and error adalah $j=\{1,2,3\}$, dimana; a) nilai $j$ sama dengan satu pada $j$, te untuk merepresentasikan indeks kondisi rendah dari trial and error, b) indeks setengah trial and error akan direpresentasikan dengan $\mathrm{j}$ yang bernilai dua pada $j$, te, dan c) tiga adalah nilai $j$ pada $j$, te untuk indeks kondisi trial and error yang tinggi. Variabel $q, t r, m$ dan $c$ untuk trial and error masing-masing memiliki bobot $(w)$. Bobot te dalam kelas $j$ adalah $w j$, te.

$\mathrm{L}=\arg \min \left\|\left\{t e_{3}, c f_{3}, e p_{3}\right\}\right\|$ $c f_{j}$ adalah nilai dari variabel careful dalam CSG (dalam formula 6), $C_{j, c f}$ adalah klasifikasi dari tingkatan careful (dalam formula 7). Tiga kelas careful adalah $j=\{1,2,3\}$ dimana; a) nilai $j$ adalah satu pada $j, c f$ adalah digunakan untuk merepresentasikan indeks untuk careful yang rendah, b) $j$ bernilai dua pada $j, c f$ adalah indeks untuk setengah careful and c) $j$ bernilai tiga pada $j, c f$ adalah indeks untuk careful yang tinggi. Bobot dari $c f$ dalam kelas $j$ adalah $w_{j, c f}$.

$$
\begin{aligned}
& x_{2, c f} \Leftrightarrow C, x_{3, \mathrm{cf}} \Leftrightarrow m, x_{4, c f} \Leftrightarrow m, x_{4, \mathrm{cf}} \Leftrightarrow q \\
& c f_{j}=\sqrt{\sum_{i}\left(x_{i, c f}-w_{i j, \mathrm{cf}}\right)^{2}} \\
& C_{j, c f}=\arg \min \left\|x_{c f}-w_{j, \mathrm{cf}}\right\|
\end{aligned}
$$

$e p_{j}$ adalah nilai dari variabel expert dalam CSG (dalam formula 9) yang mana $C_{j, e p}$ adalah klasifikasi tingkatan expert (dalam formula 10). Tiga kelas expert adalah $j=\{1,2,3\}$ dimana; a) j dengan nilai satu pada variabel $j, e p$ adalah indeks untuk expert yang rendah, b) $\mathrm{j}$ dengan nilai dua pada $j$,ep adalah indeks untuk setengah expert, dan c) $\mathrm{j}$ dengan nilai tiga pada j,ep adalah indeks untuk expert yang tinggi. Bobot dari ep dalam kelas $j$ adalah $w_{j, e p}$.

$$
\begin{aligned}
x_{1, e p} & \Leftrightarrow \mathrm{e}, x_{2, e p} \Leftrightarrow C, x_{3, e p} \Leftrightarrow m, x_{4, e p} \Leftrightarrow q \\
e p_{j} & =\sqrt{\sum_{i}\left(x_{i, e p}-w_{i j, e p}\right)^{2}} \\
C_{j, e p} & =\arg \min \left\|x_{e p}-w_{j, e p}\right\|
\end{aligned}
$$

L adalah type klasifikasi dari kondisi maksimal CS. L didefinisikan dalam tiga probabilitas kondisi maksimal, yaitu; 1) trial and error, 2) careful, dan 3) expert. CS adalah klasifikasi dari hasil CSG yang dapat didefinisikan dalam sembilan kemungkinan kondisi maksimal, yaitu; 1) trial and error yang tinggi, 2) setengah trial and error, 3) trial and error yang rendah, 4) careful yang tinggi, 5) setengah careful, 6) careful yang rendah, 7) expert yang tinggi, 8) setengah expert, and 9) expert yang rendah.

$L=\arg \min \left\|\left\{t e_{3}, c f_{3}, e p_{3}\right\}\right\|$ 


$$
\mathrm{CS}=\left\{\begin{array}{l}
C_{j, t e}, \text { if } L=t e_{3} \\
C_{j, c f}, \text { if } L=c f_{3} \\
C_{j, e p}, \text { if } L=e p_{3}
\end{array}\right.
$$

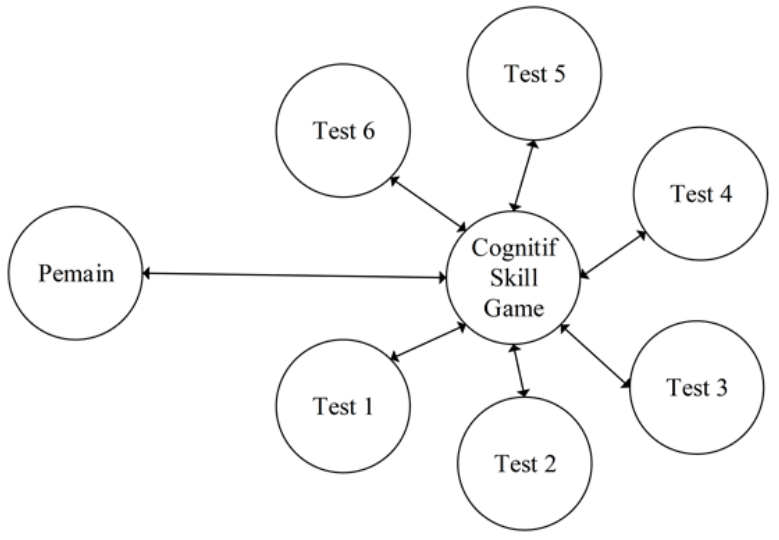

Gambar. 7. Model Alur CSG formula 12).[3]

\section{Alur Kerja CSG}

CSG ini terdiri dari enam stage yang tiap tiap stage mempunyai sub bab pertanyaan yang berbeda. Game ini tidak berlevel, player bebas menentukan pembelajaran mana yang akan diikuti lebih dulu. Banyaknya lokasi sama dengan banyaknya sub pokok bahasan dalam logika. Dari 6 stage pembelajaran yang bisa dipilih untuk menyelesaikan 6 sub pokok bahasan, yaitu:

1) Ruang transisi sebagai tempat untuk keluar masuk ke semua stage atau ruang soal.

2) Halaman tengah sekolah sebagai lokasi pembelajaran pernyataan benar atau salah.

3) Ruang guru sebagai lokasi pembelajaran pernyataan benar atau salah.

4) Ruang kelas sebagai lokasi pembelajaran perhitungan.

5) Ruang aula sebagai lokasi pembelajaran perhitungan.

6) Ruang perpustakaan sebagai lokasi pembelajaran pernyataan benar atau salah.

7) Ruang lab komputer sebagai lokasi pembelajaran pernyataan benar atau salah.

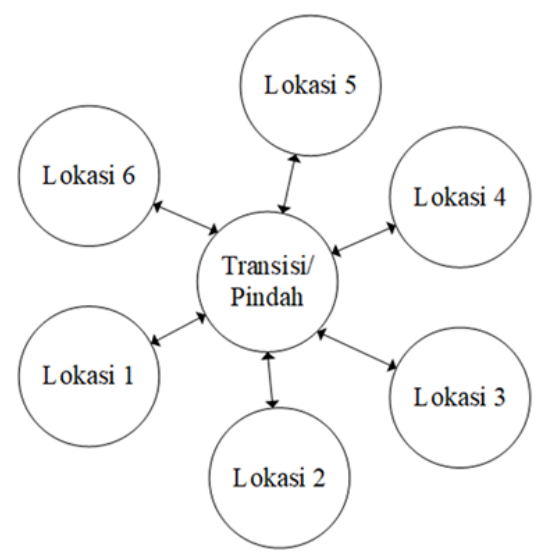

Gambar. 6. Stage CSG

Untuk menyelesaikan game tiap lokasi mencapai ketuntasan belajar, siswa cukup menjawab 12 soal dari 15 soal yang diberikan, tetapi tidak menutup kemungkinan siswa untuk mendapat poin sempurna yaitu benar semuanya. Siswa tidak bisa meninggalkan atau pindah lokasi sebelum tuntas menyelesaikan misinya.

\section{HASIL EKSPERIMEN DAN PENELITIAN}

\section{A. Dataset}

Sebagai data training peneliti melakukan survei terhadap sepuluh guru. Dengan perincian sembilan produktif dibidang TIK dan satu guru dibidang umum untuk mendapatkan tiga karakteristik keterampilan kognitif. Pertimbangan menggunakan guru sebagai responden karena guru mempunyai kemampuan menilai keterampilan kognitif terbaik. Selain itu pertimbangan lainnya adalah guru mempunyai kualifikasi sertifikasi dibuktikan dengan memiliki ijazah, sertifikat, dan pengalaman mengajar.

Dataset pada klasifikasi keterampilan kognitif dalam penelitian ini sebanyak 210 siswa. termasuk; 77 pria dan 133 wanita. Respondennya adalah para pelajar SMK sekolah. Usia responden berkisar antara 16 hingga 19 tahun. Responden digunakan untuk menguji sistem CSG. Basis CSG pada LVQ akan mengklasifikasikan kognitif siswa.

\section{B. Eksperimen dan Hasil}

Guru akan memberi bobot pada variabel referensi yang dapat mempengaruhi nilai jenis $(L)$ dan kelas $(C)$ dari keterampilan kognitif. Referensi variabel dari guru termasuk; menjawab pertanyaan $(f)$, coba jawab (gh), self efficacy $(e)$, kesalahan $(d)$, dan membatalkan $(c)$. Parameter nilai karakteristik keterampilan kognitif dapat digunakan sebagai keterampilan kognitif referensi. Yang menjadi acuan keterampilan kognitif adalah nilai keterampilan kognitif yang ideal. Nilai parameter dalam data referensi keterampilan kognitif diperoleh dari klasifikasi data survei guru. Data karakteristik keterampilan kognitif dari guru akan diterapkan pada kecepatan pembelajaran keterampilan kognitif LVQ pola.

Nilai $b, d$, dan $c$ diambil saat siswa memainkan permainan tersebut. Variabel $b, d$, dan $c$ adalah karakteristik pemain dari perilaku kognitif. Variabel tersebut adalah masukan dari CSG.

Data training yang diambil dari data guru melalui pengamatan sebelumnya sebagai acuan data dalam metode LVQ. Hasil dari pelatihan digunakan sebagai acuan nilai bobot klasifikasi keterampilan kognitif. Pada tabel 2 merupakan hasil dari pelatihan LVQ yang menggunakan data guru yang terdiri dari bobot menjawab pertanyaan $(f)$, bobot mencoba untuk jawaban $(g h)$, bobot kemampuan diri (e), bobot kesalahan $(d)$, dan bobot dari membatalkan (c). Bobot dari tabel 2 merupakan nilai keterampilan kognitif 
dalam CSG ini yang merupakan referensi klasifikasi keterampilan kognitif dari pemain.

Nilai keterampilan kognitif trial and error adalah dengan menunjukkan bobot $f$ dalam kelas $j$ bernilai $w_{1 j, t e}$ $=\{0.022,0.021,0.477\}$, bobot $g h$ dalam kelas $j$ adalah $w_{2 j, t e}$ $=\{0.030,0.026,0.317\}$, bobot $d$ dalam kelas $j$ adalah $w_{3 j, t e}$ $=\{0.040,0.030,0.175\}$, dan bobot $c$ dalam kelas $j$ adalah $w_{4 j, t e}=\{0.037,0.037,0.317\}$.

Nilai keterampilan kognitif careful menunjukkan bobot $f$ dalam kelas $j$ adalah $w_{1 j, c f}=\{0.040,0.030,0.953\}$, bobot $d$ dalam kelas $j$ adalah $w_{2 j, c f}=\{0.030,0.060,0.477\}$, dan bobot $c$ dalam kelas $j$ adalah $w_{3 j, c f}=\{0.020,0.070,0.318\}$.

Nilai keterampilan kognitif expert menunjukkan bobot $f$ dalam kelas $j$ adalah $w_{1 j, e p}=\{0.038,0.028,0.954\}$, bobot $e$ dalam kelas $j$ adalah $w_{2 j, e p}=\{0.035,0.040,0.636\}$, bobot $d$ dalam kelas $j$ adalah $w_{3 j, e p}=\{0.005,0.060,0.318\}$, dan bobot $c$ dalam kelas $j$ class is $w_{4 j, e p}=\{0.017,0.030,0.317\}$.

Tabel 2. Hasil Dataset Klasifikasi CSG

\begin{tabular}{ccccccc}
\hline \hline $\begin{array}{c}\text { Menjawab } \\
\text { pertanyaan } \\
(\mathbf{f})\end{array}$ & $\begin{array}{c}\text { Mencoba } \\
\text { menjawab } \\
(\boldsymbol{g h})\end{array}$ & $\begin{array}{c}\text { self } \\
\text { efficacy } \\
(\boldsymbol{e})\end{array}$ & $\begin{array}{c}\text { salah } \\
(\boldsymbol{d})\end{array}$ & $\begin{array}{c}\text { batal } \\
(\boldsymbol{c})\end{array}$ & $\begin{array}{c}\text { class } \\
(\boldsymbol{C})\end{array}$ & $\begin{array}{c}\text { cognitive } \\
\text { skill type } \\
(\boldsymbol{L})\end{array}$ \\
\hline 0.022 & 0.030 & - & 0.040 & 0.037 & low & Trial and \\
0.021 & 0.026 & - & 0.030 & 0.037 & semi & Error \\
0.477 & 0.317 & - & 0.175 & 0.317 & high & \\
0.040 & - & - & 0.030 & 0.020 & low & \\
0.030 & - & - & 0.060 & 0.070 & semi & Carefully \\
0.953 & - & - & 0.477 & 0.318 & high & \\
0.038 & - & 0.035 & 0.005 & 0.017 & low & \\
0.028 & - & 0.040 & 0.060 & 0.030 & semi & Expert \\
0.954 & - & 0.636 & 0.318 & 0.317 & high & \\
\hline \hline
\end{tabular}

\section{Hasil}

Hasil percobaan ditunjukkan pada tabel 3 CSG mengidentifikasi kemampuan kognitif player. CSG merepresentasikan tiga referensi keterampilan kognitif, yaitu; referensi keterampilan kognitif trial and error, careful dan expert. Ini adalah karakter multi obyektif CSG.

Kinerja pemain akan menjadi kuat dalam satu referensi keterampilan kognitif namun lemah di referensi yang lain. Obyektif yang pertama adalah expert $\left(C_{1}\right)$, obyektif yang kedua adalah carefully $\left(C_{2}\right)$, dan obyektif yang ketiga adalah trial and error $\left(C_{3}\right)$.

Dari hasil eksperimen terhadap 80 player (siswa), didapat bahwa dari persamaan (1) sampai (12), dapat dikatakan bahwa penelitian ini adalah suatu metode untuk mengetahui tiga keterampilan kognitif dan tiga tingkat klasifikasi keterampilan di setiap keterampilan kognitif. Ekspirimen menunjukkan rendahnya kompetensi dalam bermain game. Keterampilan kognitif carefully menunjukkan kemampuan yang baik dalam bermain CSG. Keterampilan kognitif menunjukkan kompetensi yang rendah dalam bermain dan dan keterampilan kognitif expert pemain memiliki kemampuan yang tinggi.

Sembilan belas persen pemain memiliki keterampilan kognitif carefully. Tujuh puluh lima persen pemain memiliki keterampilan kognitif trial and error yang tinggi, sedangkan delapan belas persen pemain memiliki keterampilan kognitif expert.

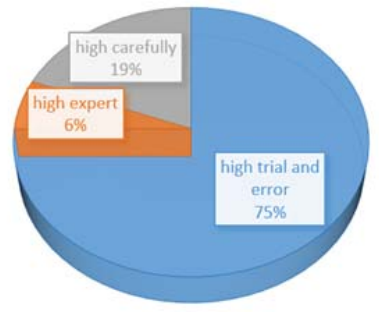

Gambar. 8. Klasifikasi Keterampilan Kognitif

Dari hasil ekspirimen pada tabel 3 juga menunjukkan pemain dengan klasifikasi kognitif high carefully memiliki type carefully dan trial \& error yang sama sebesar lima puluh persen, ditunjukkan pada gambar 8 .

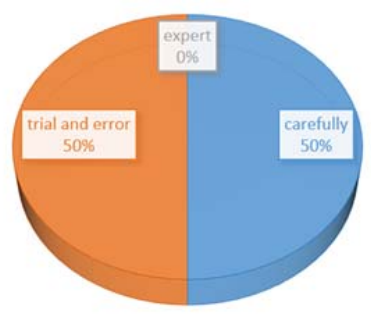

Gambar. 9. Bobot Karakter Pemain Carefully

Selain itu dari hasil ekspirimen pada tabel 3 juga menunjukkan pemain dengan klasifikasi kognitif high expert memiliki type carefully, expert dan trial \& error yang sama sebesar tiga puluh tiga persen, ditunjukkan pada gambar 9 .

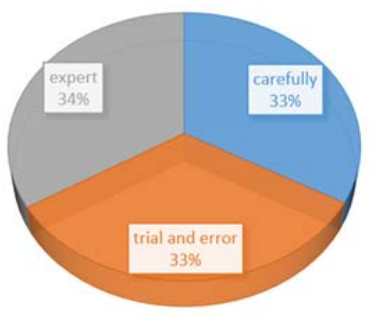

Gambar. 10. Bobot Karakter Pemain Expert

Dan dari hasil ekspirimen pada tabel 3 juga menunjukkan pemain dengan klasifikasi kognitif high trial \& error memiliki type expert dan trial \& error yang sama rata sebesar lima puluh persen, ditunjukkan pada gambar 10 .

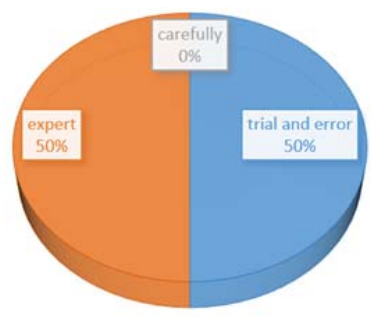

Gambar. 11. Bobot Karakter Pemain Trial \& Error

\section{KESIMPULAN}

Pada penelitian klasifikasi CSG ini, pemain dapat diklasifikasikan dalam tiga kelompok keterampilan kognitif yaitu; high trial and error $75 \%$, high expert $6 \%$, dan high careful $19 \%$ 


\section{DAFTAR PUSTAKA}

[1] A. A. Wijaya, S. Bukhori, and N. Oktavia, "Perancangan dan Pembuatan Serious Game Sebagai Simulasi Aktivitas Bisnis dan Akuntansi Menggunakan Pendekatan Agent-Based Modelling," Berk. Sainstek, vol. 5, no. 2, p. 66, 2017, doi: 10.19184/bst.v5i2.5532.

[2] J. Dibbell, Serious games, vol. 114, no. 1. 2011.

[3] M. A. Syufagi, M. Hariadi, and P. Mauridhi Hery, "A Cognitive Skill classification based on multi objective optimization using learning Vector Quantization for serious games," ITB J. Inf. Commun. Technol., vol. 5, no. 3, pp. 189-206, 2011, doi: 10.5614/itbj.ict.2011.5.3.3.

[4] M. Syufagi, M. H. Purnomo, and M. Hariadi, "Tendency of Players Is Trial and Error: Case Study of Cognitive Classification in the Cognitive Skill Games," J. Ilmu Komput. dan Inf., vol. 5, no. 1, pp. 31-39, 2012, doi: 10.21609/jiki.v5i1.184.

[5] R. Agustin, A. Purwarianti, K. Surendro, and I. Suwardi, "Model Konseptual Serious game," Researchgate.Net, [Online]. Available: https://www.researchgate.net/profile/Iping_Supriana2/publication/259 382456_Model_Konseptual_Serious_game_Berdasar_pada_kolaboras i_antara_Intelligent_Tutoring_System_dan_Game_the_Sims/links/02 e7e52b458a9e1c55000000.pdf.

[6] W. A. Setyowati and W. F. Mahmudy, "Optimasi Vektor Bobot Pada Learning Vector Quantization Menggunakan Particle Swarm Optimization Untuk Klasifikasi Jenis Attention Deficit Hyperactivity Disorder (ADHD) Pada Anak Usia Dini," J. Pengemb. Teknol. Inf. dan Ilmu Komput. Univ. Brawijaya, vol. 2, no. 11, pp. 4428-4437, 2018, [Online]. Available: http://j-ptiik.ub.ac.id.

[7] G. Barata, S. Gama, J. Jorge, and D. Goncalves, "Early Prediction of Student Profiles Based on Performance and Gaming Preferences," IEEE Trans. Learn. Technol., vol. 9, no. 3, pp. 272-284, 2016, doi: 10.1109/TLT.2016.2541664.

[8] C. Kazimoglu and L. Bacon, "An Analysis of a Video Game on Cognitive Abilities: A Study to Enhance Psychomotor Skills via Game-Play," IEEE Access, vol. 8, pp. 110495-110510, 2020, doi: 10.1109/ACCESS.2020.3001751.

[9] E. Subiyantoro and A. Azhari, "Autonomous Cognitive Leveling Game Pada Serious Game Menggunakan Particle Swarm
Optimization,” J. Buana Inform., vol. 8, no. 2, pp. 87-98, 2017, doi: 10.24002/jbi.v8i2.1080.

[10] A. R. S. Putri and G. S. Airlanda, "Pengembangan Media Pembelajaran Game PEKA Untuk Meningkatkan Hasil Belajar Kognitif Peserta Didik Pada Materi Pecahan," Efektor, vol. 7, no. 2, pp. 109-116, 2020, doi: 10.29407/e.v7i2.14978.

[11] R. Meliawati, O. Soesanto, and D. Kartini, "Penerapan Metode Learning Vector Quantization (LVQ) Pada Prediksi Jurusan Di SMA PGRI 1 Banjarbaru," Kumpul. J. Ilmu Komput., vol. 04, no. 01, pp. $11-20,2016$.

[12] P. T. Tangan, J. Syaraf, T. Learning, and V. Quantization, "JARINGAN SYARAF TIRUAN LEARNING VECTOR QUANTIZATION UNTUK APLIKASI PENGENALAN TANDA TANGAN 1 Difla Yustisia Qur'ani 1, Safrina Rosmalinda 2," vol. 2010, no. Snati, pp. 1-5, 2010.

[13] T. Kohonen, "Learning Vector Quantization," pp. 245-261, 2001, doi: 10.1007/978-3-642-56927-2_6.

[14] D. R. Oetomo, I. Kuswardayan, and N. Suciati, "Implementasi Kecerdasan Buatan Pada Permainan 'Phantom Crown' Menggunakan Hierarchical Finite State Machine dan Decision Tree," J. Tek. ITS, vol. 7, no. 1, pp. 226-230, 2018, [Online]. Available: http://ejurnal.its.ac.id/index.php/teknik/article/view/29163.

[15] E. W. Hidayat, A. N. Rachman, and M. F. Azim, "Penerapan Finite State Machine pada Battle Game Berbasis Augmented Reality," J. Edukasi dan Penelit. Inform., vol. 5, no. 1, p. 54, 2019, doi: 10.26418/jp.v5i1.29848.

[16] M. F. Rahadian, A. Suyatno, and S. Maharani, "Penerapan Metode Finite State Machine Pada Game 'The Relationship,"' Inform. Mulawarman J. Ilm. Ilmu Komput., vol. 11, no. 1, p. 14, 2016, doi: 10.30872/jim.v11i1.198.

[17] "CLASSIFICATION OF LEVEL COGNITION IN SENIOR HIGH SCHOOL ON TRIGONOMETRY COMPARISON USING TRIGONOMETRY GAME BASED LVQ METHOD.pdf." .

[18] B. Tyers, Learn RPGs in GameMaker: Studio. 2017. 
Irawan, dkk. : Klasifikasi Keterampilan Kognitif Menggunakan Metode Learning Vector Quantization dengan Bantuan Game

\section{LAMPIRAN}


Tabel 3. (Lanjutan)

\begin{tabular}{|c|c|c|c|c|c|c|c|c|c|c|c|}
\hline \multirow[t]{2}{*}{$\begin{array}{l}\text { ID } \\
\text { Player }\end{array}$} & \multicolumn{2}{|c|}{$\begin{array}{l}\text { Careful Class } \\
\text { (C1) }\end{array}$} & \multicolumn{3}{|c|}{$\begin{array}{c}\text { Trial \& Error } \\
\text { Class (C2) } \\
\end{array}$} & \multicolumn{2}{|c|}{$\begin{array}{c}\text { Expert Class } \\
\text { (C3) }\end{array}$} & \multirow{2}{*}{\multicolumn{2}{|c|}{$\begin{array}{c}\text { Cognitive } \\
\text { Skill Type (L) }\end{array}$}} & \multirow[t]{2}{*}{$\begin{array}{c}\text { Cognitive Skill } \\
\text { Classification (CS) }\end{array}$} & \multirow{2}{*}{$\begin{array}{l}\text { \% Dari } \\
\text { Semua } \\
\text { Player }\end{array}$} \\
\hline & Value & Weight & Value & & Weight & Value & Weight & & & & \\
\hline 56 & Low & 1 & High & 3 & High & 3 & Trial $\&$ & Error & Higl & Trial \& Error & \\
\hline 57 & Low & 1 & High & 3 & High & 3 & Trial $\&$ & Error & Higl & Trial \& Error & \\
\hline 58 & Low & 1 & High & 3 & High & 3 & Trial $\&$ & Error & Higl & Trial \& Error & \\
\hline 59 & Low & 1 & High & 3 & High & 3 & Trial $\&$ & Error & Higl & Trial \& Error & \\
\hline 62 & Low & 1 & High & 3 & High & 3 & Trial $\&$ & Error & Higl & Trial \& Error & \\
\hline 63 & Low & 1 & High & 3 & High & 3 & Trial $\&$ & Error & Higl & Trial \& Error & \\
\hline 64 & Low & 1 & High & 3 & High & 3 & Trial $\&$ & Error & Higl & Trial \& Error & \\
\hline 65 & Low & 1 & High & 3 & High & 3 & Trial $\&$ & Error & Higl & Trial \& Error & \\
\hline 66 & Low & 1 & High & 3 & High & 3 & Trial $\&$ & Error & Higl & Trial \& Error & \\
\hline 67 & Low & 1 & High & 3 & High & 3 & Trial $\&$ & Error & Higl & Trial \& Error & \\
\hline 70 & High & 3 & High & 3 & High & 3 & Trial \& & Error & Higl & Trial \& Error & \\
\hline 72 & Low & 1 & High & 3 & High & 3 & Trial $\&$ & Error & Higl & Trial \& Error & \\
\hline 73 & Low & 1 & High & 3 & High & 3 & Trial \& & Error & Higl & Trial \& Error & \\
\hline 74 & Low & 1 & High & 3 & High & 3 & Trial $\&$ & Error & Higl & Trial \& Error & \\
\hline 75 & Low & 1 & High & 3 & High & 3 & Trial $\&$ & Error & Higl & Trial \& Error & \\
\hline 76 & Low & 1 & High & 3 & High & 3 & Trial $\&$ & Error & Higl & Trial \& Error & \\
\hline 77 & Low & 1 & High & 3 & High & 3 & Trial $\&$ & Error & Higl & Trial \& Error & \\
\hline 78 & Low & 1 & High & 3 & High & 3 & Trial $\&$ & Error & Higl & Trial \& Error & \\
\hline 79 & Low & 1 & High & 3 & High & 3 & Trial $\&$ & Error & Higl & Trial \& Error & \\
\hline 80 & Low & 1 & High & 3 & High & 3 & Trial $\&$ & Error & Higl & Trial \& Error & \\
\hline
\end{tabular}

